\section{Corruption and the arms trade: the United Kingdom's Ministry of Defense and the bribe culture}

Nicholas Gilby

$\mathrm{B}$ ribery has long been the handmaiden of the arms trade. Richard Jordan Gatling, the inventor of the Gatling gun, wrote in the 1870 s that "our best policy will be to keep up the prices of the guns and give liberal commissions." The practice of paying commissions to agents, hidden in the overall price quoted to the customer government, has become a common method by which arms companies have passed bribes to decisionmakers. ${ }^{2}$ Although not necessarily illegal, this is corruption, or bribery, as commonly understood by the layman, where promises of payments are made by a company or individual, sometimes via intermediaries, to individuals in a position to influence decisions, with the expectation that this will buy a favorable decision for the company or individual promising the payments. ${ }^{3}$

Arms exports are necessary to enable the U.K. government to achieve its objective of sustaining the country's arms industry. ${ }^{4}$ But to export arms, U.K. arms companies seem to need to pay bribes. ${ }^{5}$ (The government, which for forty years has actively promoted arms exports, ${ }^{6}$ has, however, always denied being complicit in bribery by arms companies. ${ }^{7}$ ) Using previously unpublished material, this article considers exactly how the U.K. Ministry of Defense (MoD) has interacted with the "bribe culture" that has surrounded international arms deals. ${ }^{8}$ It argues that there were two basic phases. The first, in which the MoD directly paid commissions to agents, used a subsidiary of the Crown Agents as a front, facilitated bribery by private companies, and provided intelligence on corruption to U.K. companies. The second phase, after the Lockheed scandal in the United States in 1975-76, ${ }^{9}$ saw the MoD trying to avoid acquiring knowledge of bribes and to avoid asking awkward questions. In essence, this left bribes on government-to-government deals to be paid by U.K. companies, and misled Parliament about the truth.

The following sections explore these assertions in some detail.

In-house involvement

Up to the 1970 s, there is evidence that the U.K. government actively participated in arms trade corruption in four ways. First, the MoD, when selling surplus MoD weapons or weapons produced by nationalized companies, directly employed agents in the expectation they would indulge in bribery. This was evident prior to the setting up of the Defense Sales Organization, DSO (which became the Defense Export Services Organization, DESO, in 1985), when the Director of Sales at the MoD,
Harold Hubert, told the embassy in Tehran in July 1964 that he wanted an agent to secure arms deals in Iran. Hubert complained of "loud protests about the encouragement of graft. My own reaction to this is that I am not keen to educate the Persians in virtuous ways." He asked his agent to sell "through the back door."10 Hubert admitted to the Foreign Office that in Saudi Arabia, Alamuddin, the agent he wanted to use in Iran, had used the Zahid brothers, whom, Hubert said, "operate by graft." The Zahid brothers, he wrote, "gave me immediate access to the Minister of Defence," Prince Sultan, then and now the Saudi Minister of Defense. ${ }^{11}$

In May 1965 Hubert sold Geoffrey Edwards 10,000 Lee Enfield .303 rifles and 6 million rounds of ammunition. ${ }^{12}$ The arms were to be sent to Saudi Arabia. Edwards was the agent in Saudi Arabia of BAE Systems's forerunner, the British Aircraft Corporation (BAC). Edwards, the Foreign Office believed, passed bribes to secure arms deals. ${ }^{13}$ Hubert pointed out that "the rifles which we sold to Edwards for $£ 7.15 .0 \mathrm{~d}$ delivered in Jedda were re-sold to the Saudi Government for £15.” Clearly showing he believed that bribes had been paid, Hubert wrote "a profit of this sort (on ammunition as well) has no doubt to be shared." The Foreign Office wrote to the embassy in Jedda that "any sweetening of the Saudis is a matter for Edwards and not the Ministry of Defence." 14 The embassy replied that "certain military officers received bribes in consideration of passing the rifles as satisfactory." 15

When, in early 1967, a U.K. embassy official in Caracas asked Hubert whether the government were prepared, through an agent, to enter into a government-togovernment contract involving bribery ${ }^{16}$ Hubert replied "I am completely mystified by just what your problem is ... people who deal with the arms trade, even if they are sitting in a government office, live day by day with this sort of activity, and equally day by day they carry out transactions knowing that at some point bribery is involved. Obviously I and my colleagues in this office do not engage in it, but we believe that various people who are somewhere along the lines of our transactions do. They do not tell us what they are doing and we do not inquire. We are interested in the end result." ${ }^{17}$ Leonard Figg of the Foreign and Commonwealth Office's (FCO) Defense Department replied that "we accept the proposition that an agent acting in a government-to-government deal (or of course firm-to-government) should get his commission and the price HMG charge must reflect this cost." 18

Later that year DSO promised $£ 50,000{ }^{19}$ to an agent "to help with the promotion of the Chieftain Tank sale to Holland because of the influence it was considered he could bring to bear in influential quarters." ${ }^{20}$ The Treasury believed the agent was Prince Bernhard, ${ }^{21}$ widely believed to be "on the take." 22 In 1975 Bernhard was removed from public duties after it was revealed he had requested $\$ 4$ million to $\$ 6$ million in commission from Lockheed on the Dutch purchase of F-104 Starfighter aircraft. ${ }^{23}$ Defense Secretary Denis Healey was told in 1969 that "the [Chieftain] deal did not come off and no money was paid" but that another agent ${ }^{24}$ had been hired to sell the $30 \mathrm{~mm}$ Rarden Gun to Holland. ${ }^{25}$

In early 1969, the MoD used Shehadah Twal to sell Royal Ordnance Factory 
Overall, there is considerable evidence that prior to the mid-1970s the British government was aware of arms deal corruption, and that it participated in this corruption in various ways. For the period thereafter, an argument can be made that government knowingly "subcontracted" arms-related corruption to other agents. of DSO, told Defense Secretary Denis Healey that Twal had been hired because of "the need to have individuals at the Department's disposal to ensure that those able to influence where orders may go are appropriately recompensed by the agents." ${ }^{29}$ Twal was promised $2.5 \%$ "commission" in $1969 .{ }^{30}$ On 5 November 1970, DSO sold 16 Centurion tanks to Jordan for $£ 16,500$ each. Twal was "incurring considerable expenditure on sales promotion and entertainment" ${ }^{31}$ and on 22 June 1971 was paid his commission. ${ }^{32}$ The MoD canceled the agreement in June 1972 as Twal had not had further success. ${ }^{33}$ This hiring of agents by the MoD was authorized by ministers and very senior officials. ${ }^{34}$ Even Defense Secretary Denis Healey was aware of the arrangements regarding Holland, and he and Defense Minister Ian Gilmour knew of the MoD's employment of Alamuddin (Alamuddin was promised 2.5\% "commission" on sales) in the Lebanon and Twal in Jordan. ${ }^{35}$

Second, there is evidence that the MoD used Millbank Technical Services (MTS), a wholly owned subsidiary of the Crown Agents for Overseas Governments and Administrations, as a front to pass on bribes. The Crown Agents were financial, professional, and commercial agents for overseas governments and public bodies. ${ }^{36}$ Working with DSO, it offered "to defence forces overseas a comprehensive range of technical supply and support services." ${ }^{37}$ Crucially, MTS was able and willing to pay "agents commissions." 38

At the start of the 1970s DSO were heavily involved in an attempt to sell the Saudi Arabian National Guard (SANG) five armoured battle groups ${ }^{39}$ for $£ 112$ million. ${ }^{40}$ SANG Commander Prince Abdullah (now King of Saudi Arabia) pressed for a formal government-to-government deal ${ }^{41}$ and the MoD answer was to use MTS. The Head of DSO, Lester Suffield, explained to Defense Secretary Lord Carrington's Private Secretary in 1972 that "because of the usual considerations that apply to any business in Saudi Arabia i.e. the need to pay 'commissions' and because also Prince Abdullah wished to give any purchase the appearance of a Government-to-Government deal, we proposed to Prince Abdullah that a middle course would be to make the U.K. package offer through Millbank Technical Services. ${ }^{, 42}$ Earlier Hubert had explained that "there might be advantages in MTS co-ordinating any British equipment business to provide the quasi-Government oversight as well as passing on the douceurs." ${ }^{43}$ MTS employed Abdullah's brother-in-law, Fustuq, as their agent. ${ }^{44}$

Ministers were told "at various times other 'fixers' tried to get in on the act and we did our best to string them along while continuing to deal through the channel Abdullah desired [Fustuq]." With the deal slipping away from the United Kingdom, Hubert advised that MTS should try and do a deal with Khashoggi (who represented the big U.S. arms companies) and "we should go for it and pull out all the stops. If a deal has to be done with Khashoggi it should be done. His own personal demands will probably be high, but that is the way business is done in Saudi Arabia, the King's edict about 25 percenters notwithstanding. Either Khashoggi is offered the cut he wants or we should pull out." 45 Khashoggi had previously been used as an "agent" on arms deals by the MoD, ${ }^{46}$ but the United States eventually secured the deal.

Third, there is evidence that bribery by private companies was facilitated by U.K. officials. General Makki Tounisi, the Director of Operations in the Saudi Army, asked Jedda Defense Attaché Colin Fitzpatrick for a substantial bribe (3.5 percent of the contract price) for the sale of Vickers private venture tanks to the Saudi Army. This bribe request was duly passed to Vickers by Fitzpatrick. ${ }^{47}$ Colonel Bernard Heath of Vickers told his superiors that Hassan Gabr, chief interpreter to Saudi Defense Minister Prince Sultan, had said "everyone else used agents and that no deal would go through unless Sultan and the Army Officers got a cut."48

Last, there is evidence that the DSO consulted "fixers" to glean intelligence for U.K. arms companies. In January 1971 Adnan Khashoggi met DSO in London to advance his proposals for a "systems management organisation" for the Saudi Arabian Air Defense scheme. ${ }^{49}$ Khashoggi was also consulted by DSO over the attempts by Vosper Thorneycroft to sell ships in the early 1970 s. ${ }^{50}$ By the early 1970 s senior DSO officials such as Harold Hubert and Reg Anderson were meeting Khashoggi at least monthly to discuss arms sales, and hoped he could generate business as well as intelligence. Hubert observed "to K pressing for or against a particular equipment was not appreciably affected by its military qualities." Hubert said to Khashoggi "naturally we should not interfere with commissions paid to him by firms." ${ }^{51}$ Meetings between DSO and Khashoggi took place in February 1972,52 late March 1972,53 and in May and November 1972. ${ }^{54}$ The relationship continued into the mid-1970s, and in 1974 DSO met with Khashoggi and others to discuss the sale of Rapier. ${ }^{55}$

Overall, there is considerable evidence that over this period the government was aware of corruption in arms deals and participated in various ways. The advent of the Lockheed scandal in 1975-76 changed everything. Until then no questions had to be asked about what activities the agents undertook. ${ }^{56}$ But, post-Lockheed, questions might be asked, and new MoD Permanent Secretary Sir Frank Cooper was worried about the answers. An MoD official for many years, Cooper almost certainly knew that, as Chancellor and former Defense Secretary Denis Healey later said in 1977, "there was no doubt that bribery had been going on for years on a large scale in the 
Middle East and Africa, and that organisations responsible to Government (including Defence Sales and nationalised industries) had been involved." ${ }^{57}$

\section{Subcontracting corruption}

In May 1976, Cooper decided that "in view of the current interest in the subject of special commissions" guidelines were needed. ${ }^{58}$ His directive, issued on 9 June 1976, stated that public money was not to be used for illegal or improper purposes, that officials should not engage in or encourage illegal acts, that DSO should avoid employing agents, and if any agent was employed by DSO they should be reputable and not demand an "excessive" fee..$^{59}$ This might have seemed a reasonable response, but as agents could still be employed by private or nationalized companies with the knowledge of the MoD, it failed to do more than lead to the subcontracting of corruption.

This became evident in 1977 when Comptroller and Auditor General, Sir Douglas Henley, was investigating the MoD's contract with BAC to provide the Saudi Arabian Air Defense Project (SADAP). In the deal payments were made by the Saudis to BAC via the MoD's accounts. BAC had told the MoD they had to pay 10 percent in “consultants' fees" - over $£ 30$ million. ${ }^{60}$ The MoD’s lawyer made clear Henley’s purpose: "the question he is asking is whether we have satisfied ourselves as to the propriety of accepting the payments." ${ }^{61}$ MTS had by then commissioned a legal opinion on the question of corruption. Using this opinion, Henley noted that in the SADAP case none of the three criteria MTS's lawyers had seen as necessary to avoid corruption had been met. Rates of commission were much higher than those paid for Iranian or Kuwaiti arms contracts; no information was provided as to the recipients of the consultants' fees; and a separate confidentiality agreement had been requested. ${ }^{62}$

The MoD commissioned its own legal advice from the Treasury Solicitor's Department who replied "MoD are not aware of the identity of the agents nor of the details of their services and that they have no means themselves or knowing whether the payments are excessive for the services rendered." The advice then stated that because of this the MoD could not know whether public money had been used for illegal or improper purposes and thus was in breach of Cooper's June 1976 directive. ${ }^{63}$ The legal advice was that "the Department is entitled to obtain full information in relation to the payments. Whether or not this is practicable is, however, a matter for administrative decision." ${ }^{64}$ A suggestion that the MoD should ask BAC for further information about its agents and their services prompted Cooper's Private Secretary John Howe ${ }^{65}$ to minute "I don't really like the way this is going and what may be unearthed." ${ }^{66}$ Howe wrote "we do not have a responsibility for going to some pains to discover what agents are employed by firms or exactly what the arrangements are between firms and agents" and that Cooper felt it was "business which is properly the companies' and not our own." ${ }^{67}$
As a result he merely asked BAC for an assurance that "the third party consultants to whom the fees in question are paid are reputable companies and individuals; and that in your company's opinion you are obtaining an adequate return through the services performed by third party consultants for the fees which you pay. Finally I should be grateful if you would confirm that the position of these consultants in relation to the contract is acceptable to the appropriate Saudi authorities." BAC agreed to provide the assurance provided that the last sentence was qualified by the phrase "to the best of your knowledge and belief." ${ }^{68}$ This was a crucial qualification for it absolved BAC of responsibility should it turn out that (officially) the Saudi government were not aware of BAC's agency arrangements (as they almost certainly were not). The assurance was given and Cooper stressed this to Henley, neatly evading the point that SADAP had not been in compliance with his own directive about the use of agents by failing to mention to Henley that the assurances had only very recently been received. ${ }^{69}$ Cooper then told Henley the MoD had "not thought it necessary to know the identity of the recipients" as long as BAC gave assurances. ${ }^{70}$ His parting shot was that "it is accepted Government practice to avoid over extensive enquiries. We must have regard for the risk of unnecessary interference in industry's business and for placing firms at a disadvantage with their competitors." "11 As a concession Cooper reissued his 1976 directive to DSO. It was amended so that in cases where firms asked for MoD approval for fees or commissions to be included in the final price, the MoD should obtain assurances from the firm that the agents are reputable, providing "an adequate return" for the payments, and "to the best of the firm's knowledge" the position of the agents should be accepted by the customer government. ${ }^{72}$

Cooper's amended guidelines certainly made it easy for the government to turn a blind eye to corruption, by accepting companies' word that nothing was wrong at face value, while private arms sales did not require MoD approval of specific contract terms. Why the MoD wanted to avoid knowledge and further enquiries by Douglas Henley became clear two weeks later in June 1976 when the Head of Defense Sales, Lester Suffield, gained Cooper's approval for "agency fees" of 15 percent on the SADAP II deal and for the same level of "agency fees" on a contract for communications for SANG. The "fees" would be paid by the MoD's subcontractors - BAC and Cable and Wireless, respectively. ${ }^{73}$ In the draft of Suffield's minute to Cooper asking for approval, the fees were described as amounting "in practice to the exertion of influence to sway decisions in favour of the client" and that senior Saudis "would certainly not approve the payment of fees, although they undoubtedly expect appropriately discreet arrangements to be made." "7t appears that some MoD officials did believe that the payments were essentially corrupt.

This episode provides an illuminating insight into the culture change that the Lockheed and British Leyland corruption allegations had wrought in the MoD by the mid-1970s. The MoD tolerated "commissions" on arms deals, and the documents contain many tacit admissions of knowledge, or suspicion, about what the arms 
companies were up to. But while running deals like SADAP through the MoD accounts and promoting private arms sales, senior officials tried to avoid knowledge of, and prevent the Exchequer and Audit Department discovering, what lay beneath. ${ }^{75}$

Turning a blind eye

Archival evidence about the government's role in the U.K.'s arms trade is, generally, only available up until 1976. But what little evidence there is after that point does tend to suggest that the government's avoidance of knowledge of bribery in arms sales continued in the 1980 s.

In January 1986 the former Group Marketing Director at British Aerospace (BAe) and then Head of Defense Export Services at the MoD, Colin Chandler, met Prince Sultan in Riyadh to conclude the Al Yamamah arms deal (the U.K.'s biggest ever). ${ }^{76}$ Chandler's telegram on the negotiations said that the price of each IDS variant Tornado had risen from $£ 16.3$ million in May 1984 to $£ 21.5$ million, and the price of each Hawk trainer from $£ 4$ million to $£ 5.3$ million. ${ }^{77}$ This represented a price rise on both types of aircraft of 32 percent over a period of 19 months. Inflation in the United Kingdom between May 1984 and January 1986 was around 9.5 percent. No reason was provided in the telegram to London for the dramatic price rise, ${ }^{78}$ although Patrick Wright, the Ambassador in Riyadh who was at the meeting with Chandler and Sultan, would probably have been aware of the possibility of corruption. In 1974 when Head of the FCO's Middle East Department, DSO official Ian McDonald had told Wright "the 'fiddle factor' was an element that could not be overlooked" Saudi Arabia ${ }^{80}$ Despite this, the now available U.K. government documents on the negotiations ${ }^{81}$ contain no discussion by any officials about the possibility of corruption at all, suggesting the MoD preferred not to know. Indeed, the still suppressed National Audit Office report into Al Yamamah, according to Robert Sheldon, one of its authors, was "not able to follow money outside the department once it is paid to the contractors, so we do not know what was done with it." 82

Cooper's 1977 guidelines were updated by the Permanent Secretary Sir Christopher France in November $1994 .{ }^{83}$ The revised guidelines stressed that "commissions" were the business of the companies only - DESO was forbidden to employ agents. Arms companies were, however, given more flexibility in government-to-government deals. The MoD dropped the requirement for assurances, demanding only that companies were told the MoD believed companies should only employ "reputable companies or individuals" and ensuring the agents provided "an adequate return for ... payments." ${ }^{84}$ This directive essentially amounted to the MoD relaxing its standards from the late 1970 s.

In March 2001 the Chief Executive of the Serious Fraud Office, Rosalind Wright, wrote to Permanent Secretary at the MoD, Kevin Tebbit, about the allegations of Edward Cunningham, a former employee of Robert Lee International (RLI), a company linked to BAe. The Guardian newspaper has alleged RLI was running a "slush fund" for Saudi royals. Wright wrote "I thought it right to draw this to your attention since it is conceivable that Government money has been misused." that month Tebbit replied saying he had "no wish to set damaging hares running, but given the sensitive issues raised in your letter, I have conducted a discreet initial exploration of the allegations' implications." ${ }^{86}$ In a move reminiscent of Cooper in 1977, Tebbit asked the Chairman of BAE, Sir Richard Evans, about the allegations: "The Chairman told me that this was an old story and reaffirmed BAES' commitment to operation within the law in all countries in which the company was involved." Defense Secretary Geoff Hoon told Labour MP Gavin Strang that "Sir Kevin looked into the issue at the time and was satisfied that the allegations were of no relevance to the MoD and that no contractual impropriety regarding Government employees existed." ${ }^{88}$ Around this time the Serious Fraud Office began its investigation into the Al Yamamah "slush fund" allegations which lasted until late 2006, but which was curtailed following lobbying by the Prime Minister and BAE Systems.

More recently, allegations have emerged that for at least 10 years BAE Systems paid $£ 30$ million every quarter to a U.S. bank account controlled by Prince Bandar bin Sultan, the son of Saudi Defense Minister Prince Sultan, as part of the Al Yamamah deal. ${ }^{89}$ An investigator for the bank told the BBC "there wasn't a distinction between the accounts of the Embassy or official government accounts as we would call them and the accounts of the Royal Family." Prince Bandar has denied the payments were corrupt. The BBC claimed that, like SADAP, the payments were made via the MoD accounts, due to Al Yamamah being a government-to-government deal. Until more documents are available, the truth will be impossible to establish. But it appears inherently unlikely that MoD officials processed quarterly invoices from Prince Bandar as the BBC alleged. It is possible that Al Yamamah was similar to SADAP, with payments being made by the MoD to BAe, who then paid for "support services," with the MoD turning a blind if knowing eye..$^{90}$

Frank Cooper's determination to avoid "unnecessary interference in industry's business" has thus persisted in the MoD to this day. Current policy is that "all decisions on the employment of agents and on their remuneration are matters for the companies" and DESO "is now concerned only with responding to requests ... for assistance in determining whether to employ an agent, or for information about reputable agents." 91

\section{Misleading Parliament}

Throughout the period, Parliament has generally been kept in the dark. In the 1970s, during Henley's investigation into SADAP, an MoD lawyer made clear the MoD's anxiety to avoid parliamentary scrutiny on the issue of corruption. She wrote of Henley that "he is still concerned about the whole subject of agents' commission in its various forms, but in a longer-term context. Like us he cannot overlook the danger of the Public Accounts Committee (PAC) rambling on to the subject but I think this 
would be as unwelcome to him as to us." ${ }^{92}$ Henley felt that in the light of the British Leyland bribery allegations in the Daily Mail the SADAP transactions' "unusual nature and large magnitude are such that Parliament would now expect them to receive very special scrutiny and to be informed of the situation. ${ }^{93}$ It was not

In 1978, FCO official Derek Thomas, struggling to answer a Parliamentary Question asking "how many cases of corruption involving alleged bribery by British companies had come to the notice of the Foreign and Commonwealth Secretary during the last five years and how many such cases were connected with arms contracts," wrote "I find that it is impossible to state categorically that no such cases had come directly to Dr. Owen's notice in his capacity as Foreign and Commonwealth Secretary. This would simply not be true." 94 Thomas arranged for Frank Judd, FCO Minister of State, to merely reply that "the enforcement of legislation and general standards relating to business activities is a matter for the appropriate authorities acting within their own jurisdiction." ${ }^{95}$

At the end of the 1970s Cooper found himself before Parliament trying to defend actions that had been taken under his own guidelines. International Military Services (IMS), the successor to MTS, was found to have deposited just under half a million pounds into a Swiss bank account as "consultancy" on an arms deal. The MoD told the Public Accounts Committee, a powerful Parliamentary committee that scrutinizes government expenditure, that it did not "condone" bribery, a statement that as we have seen was dishonest. It emerged that, following Cooper's own guidelines, the MoD had "undertaken not to require IMS to supply documentation relating to the company's commercial partnerships with third parties," and as a result Cooper conveniently could not be certain whether or not a bribe had been paid. ${ }^{96}$

An article in The Guardian in 2003 claimed that "bribery has been at the heart of DESO's mission from the day the unit was launched nearly 40 years ago," and that the "UK secretly connives at such payments." 97 The article was fiercely rebutted by the MoD in a response to a parliamentary inquiry as "totally without foundation" and irresponsible." ${ }^{98}$ While Parliament's Quadripartite Committee still accepts the MoD denials, ${ }^{99}$ the MoD's defense ${ }^{100}$ relies on the revised Cooper's 1976 guidelines, which, as we have argued, were designed to allow them to turn a blind eye. These were largely meaningless, as, two weeks after their promulgation, MoD officials apparently believed that payments made on a government-to-government deal with Saudi Arabia were essentially corrupt. Sadly, Parliament continues to be misled.

\section{Conclusions}

If we accept Joe Roeber's plausible contention that the international arms trade is "the most corrupt of all legal international trades," "101 then the MoD's close involvement with the international arms trade means that it is inevitably complicit in corruption. The evidence presented here suggests, however, that it has been more than complicit and that its insistence on the propriety of its own conduct is questionable. Newly available evidence documents the involvement of the government in corruption before the mid $1970 \mathrm{~s}$, and since then it appears to have deliberately chosen a strategy of closing its eyes to the corruption it actually suspects. This is particularly the case in the Al Yamamah arms deal, where MoD has been more closely involved than any other U.K. arms deal. It has acted as government sponsor, committing its own staff to the servicing of the contract, and lobbying for loan guarantees and for a new lucrative contract known as Al Salam. ${ }^{102}$ The allegations about corruption in the Al Yamamah deal have been sustained, from multiple credible sources and thoroughly documented. Yet the MoD's response has been to ignore them. When pressed by the Serious Fraud Office (SFO) it merely sought unsubstantiated assurances from BAE Systems. And once the SFO did investigate, it participated in the lobby for the investigation to be stopped, as Defense Secretary Des Browne did in the autumn of $2006 .^{103}$

For the last forty years the MoD has faced a choice - accepting corruption or making a serious attempt to stamp it out. It has chosen the former. The likely costs of this choice are high. A bribe culture "undermines democratic accountability, diverts resources from the public good and into private pockets, and 'redistribut[es] wealth and power to the undeserving.' Corruption can also increase inequality and poverty," 104 and generate demand for arms that could increase the likelihood of conflict. It also undermines democracy in the United Kingdom, and in the words of former DSO employee Harold Hubert "besmirch[es] the good name of the British Government." 105

To be able to stamp out corruption, the truth would need to be faced openly and honestly so that effective solutions can be put forward. ${ }^{106}$ To this end the government should remove its support for a corrupt trade, the National Audit Office (NAO) report into Al Yamamah (the only NAO report still secret) should be published, the Serious Fraud Office investigation into Al Y amamah should be reinstated, and an independent enquiry into the whole affair should be launched. The U.K. government needs to bring in effective corruption legislation, and, more importantly, enforce it. This may lead to some embarrassment to the government, but the potential benefits are significant

\section{Notes}

Nicholas Gilby is a researcher and author. He has carried out extensive research ove a number of years for Campaign Against Arms Trade (CAAT) in London. He may be reached at CAAT, 11 Goodwin Street, London, N43HQ or enquiries@caat.org.uk.

1. Phythian (2000, p. 85).

2. For reasons of brevity I do not intend to substantiate this point in this paper. Those who are skeptical about this assertion can turn to the following for enlightenment (this is not an exhaustive list of the relevant literature but they give a good overview of the 
subject): Boulton (1978); Phythian (2000, pp. 84-96); Roeber (2005). In the United Kingdom. there have also been many allegations in recent years concerning bribery by BAE Systems and a company it now owns - Alvis plc - in Saudi Arabia, Indonesia, South Africa, Romania, Tanzania, the Czech Republic, Chile, and Qatar. These allegations have been given extensive coverage, particularly in The Guardian. Aside from Saudi Arabia and Indonesia, all the allegations are being investigated by the Serious Fraud Office (SFO). BAE Systems and Alvis have always denied the allegations.

3. Until 2001 the relevant anti-corruption legislation was the Prevention of Corruption Act 1906. Subsection 1(1) of the Act states "if any person corruptly gives or agrees to give or offers any gift or consideration to any agent as an inducement or reward for doing or forbearing to do, or for having after the passing of this Act done or forborne to do, any act in relation to his principal's affairs or business, or for showing or forbearing to show favour or disfavour to any person in relation to his principal's affairs or business ... he shall be guilty of a misdemeanour." It is the view of the U.K. government, as reported by the OECD, that "there is no legal impediment to applying these offences to the bribery of foreign public officials" (see OECD, 2000, p. 3). The U.K. government told the OECD that the Prevention of Corruption Act 1906 also applies where a bribe is made via an intermediary (ibid, p. 5). Further the U.K. government told the OECD that under section 8 of the Accessories and Abettors Act 1861 , "any person who aids, abets, counsels, or procures a criminal offence, statutory or at common law, may be prosecuted" (ibid, p. 7). The government has also stated that "section 31, sub-section (1) of the Criminal Justice Act of 1948 provides that where any British subject employed by HMG in the U.K., when in a foreign country and acting in the course of his employment, commits an offence which if committed in England would be punishable on indictment, then that individual shall be guilty of an offence" (Quadripartite Committee, 2007, paragraph 341, p. 136). The OECD noted, however, that "the courts did not have jurisdiction to try a bribery offence unless some part of the corrupt transaction took part in the United Kingdom" (OECD, 2003 , p. 5). The OECD noted in 2005 that "despite the longstanding existence of bribery offences in the UK... [there have been no ] known convictions of legal persons for domestic or foreign bribery under the common law, the 1889 Act or the 1906 Act. There is also scant evidence of any prosecution of legal persons" (OECD, 2005, pp. 64-65). The difficulties inherent in prosecution are graphically illustrated in the Al Yamamah "slush fund" case where BAE Systems were alleged to have run a "slush fund" for leading Saudi Princes. The SFO investigation was controversially suspended in December 2006. Part of the reason for this was that the then-Attorney General, Lord Goldsmith, took the view that a prosecution was impossible as BAE Systems had asserted the payments had been authorized at the highest level in Saudi Arabia. Under the 1906 Act the person receiving the bribe (the "agent") has to be acting against the interests of his "principal," i.e., organization. Effectively Goldsmith took the view that as in Saudi Arabia the royal family (who were allegedly the beneficiaries of the "slush fund") are the state, BAE Systems' defense would succeed (Adams, et al., 2007). Because of the legal complexities, this article does not attempt to define the practices described as legal or illegal, but instead relies on the ordinarily understood definition of corruption, which arguably should guide the government more than mere legal considerations.

4. Ministry of Defense (2005, pp. 46-47).

5. In the words of Joe Roeber, the arms trade is "the most corrupt of all legal international trades." See Roeber $(2005$, p. 5).

6. For example the government used a dedicated unit of around 500 civil servants, the Defense Export Services Organization (DESO), to push for arms exports (DESO however is due to be closed by the end of 2007). There are a variety of other ways, direct and indirect, that the government uses to support arms exports.

7. Quadripartite Committee (2004, Ev 34) and, more recently, Quadripartite Committee (2006, p. 24).

8. The Freedom of Information Act (2000) has been important in enabling some of the material in this article to reach the public domain. Previous publication of some of the material in the article has resulted in the documents cited being withdrawn from public view. Section 4(6) of the Public Records Act 1958 (which is still in force) states that "public records in the Public Record Office or other place of deposit appointed by the Lord Chancellor under this Act shall be temporarily returned at the request of the person by whom or department or office from which they were transferred." This was the fate of files DEFE 23/149 and PJ 5/40, cited in this article.

9. An investigation by the U.S. Senate Sub-Committee on Multinationals under Senator Frank Church had uncovered massive bribes paid by a major U.S. arms company, Lockheed, to secure contracts.

10. The National Archives (TNA). 5 March 1965. Letter from H.R. Hubert, MoD, to I.R. Courtney, British Embassy, Tehran. FO 371/180660.

11. TNA. 24 March 1965. Letter from H.R. Hubert, MoD, to W. Morris, FO, 24 March 1965, TNA. FO 371/180660.

12. TNA. 12 May 1965. Minute from D.I. Morphet, FO. BS 1192/77, FO 371/179889. 
13. TNA. 22 July 1965. Jedda Telegram No.72 to MoD, copied to FO. BS 1192/96, FO $371 / 179890$.

14. TNA. 11 August 1965. Letter from D.I. Morphet, FO, to J.M. Brown, British Embassy, Jedda. BS 1192/96, FO 371/179890.

15. TNA. 25 August 1965. Letter from J.M. Brown, British Embassy, Jedda, to D.I Morphet, FO. BS 1192/96, FO 371/179890.

16. TNA. 18 January 1967. Letter from D.N. Brinson, British Embassy, Caracas, to L.C.W. Figg, FCO. FCO 46/190.

17. TNA. 2 February 1967. Letter from H.R. Hubert, MoD, to D.N. Brinson, British Embassy, Caracas. FCO 46/190.

18. TNA. 22 February 1967. Letter from L.C.W. Figg, FCO, to D.N. Brinson, British Embassy, Caracas. FCO 46/190.

19. TNA. 5 September 1967. Letter from J. Moreton, MoD, to J. Patterson, HM Treasury. T 225/2918.

20. TNA. 15 October 1969. Minute from R.F. Brown, MoD, to Denis Healey. http://image.guardian.co.uk/sys-files/Guardian/documents/2007/05/28/ch02doc 080910.pdf [accessed 22 September 2007]

21. TNA. 5 September 1967. Letter from J. Moreton, MoD, to J. Patterson, HM Treasury. T 225/2918.

22. Sampson (1977, p. 123).

23. Phythian (2000, p. 87).

24. Colonel Douwes Dekker of Goliath Limited. TNA. 1 September 1976. Draft reply to letter from Sir Douglas Henley, Exchequer and Audit Department to Sir Frank Cooper, MoD. PJ 1/43.

25. TNA. 15 October 1969. Minute from R.F. Brown, MoD, to Denis Healey. http://image.guardian.co.uk/sys-files/Guardian/documents/2007/05/28/ ch02doc080910.pdf [accessed 22 September 2007].

26. Twal worked for The Commercial and Industrial Company in Amman. TNA. 19 February 1969. Letter from T.E. Nissen, MoD, to S.S. Twal. DEFE 68/96.
27. At this time Nissen was Deputy Director of Army Sales in the MoD; Hubert was Director of Army Sales.

28. TNA. 4 August 1969. Minute from T.E. Nissen, MoD, to C. Hewertson, MoD DEFE 68/96.

29. TNA. 15 October 1969. Minute from R.F. Brown, MoD, to Denis Healey. http://image.guardian.co.uk/sys-files/Guardian/documents/2007/05/28/ch02doc080 910.pdf [accessed 22 September 2007].

30. TNA. 24 November 1969. Agreement between the United Kingdom Ministry of Defence (Directorate of Army Sales) and The Commercial and Industrial Company Limited, Amman, represented by Mr. Shehadah Twal. DEFE 68/96.

31. TNA. 4 December 1970. Minute from T.E. Nissen, MoD, to H.R. Hubert, MoD DEFE 68/96.

32. TNA. 10 July 1972. Minute from T.E. Nissen, MoD, to H.R. Braden, MoD. DEFE $68 / 96$.

33. TNA. 15 June 1972. Letter from H.R. Braden, MoD, to S.S. Twal. DEFE 68/96

34. Defense Secretary Denis Healey was told by his Permanent Secretary, Sir James Dunnett, in September 1967 that "instructions have been issued to ensure that any proposals to employ agents on MoD behalf are submitted to at least DUS level and where considered appropriate, to Ministers." DUS level is Deputy Under Secretary level, one grade lower than Permanent Secretary, the grade of the top MoD official. TNA. 21 September 1967. Minute from I.J. Dunnett, MoD, to Denis Healey. DEFE $13 / 509$.

35. TNA. 15 October 1969. Minute from R.F. Brown, MoD, to Denis Healey http://image.guardian.co.uk/sys-files/Guardian/documents/2007/05/28/ch02doc080 910.pdf [accessed 22 September 2007]. TNA. 21 May 1971. Minute from R.L.L. Facer, MoD, to APS/Minister of State, MoD. DEFE 68/96.

36. MTS was a private company incorporated on 11 December 1967. TNA. March 1975. Interim Report on Millbank Technical Services Limited, Coopers and Lybrand Chartered Accountants, p. 3. CAOG 18/676.

37. TNA. Final Draft MTS Brochure. CAOG 22/27. 
(C)www.epsjournal.org.uk - Vol. 3, No. 1 (2008)

38. TNA. March 1975. Interim Report on Millbank Technical Services Limited, Coopers and Lybrand Chartered Accountants, p. 10. CAOG 18/676.

39. TNA. Presentation to His Royal Highness Prince Abdullah Bin Abdul Aziz, Commander, Saudi Arabian National Guard. DEFE 68/239.

40. TNA. 3 March 1972. Minute from H.J.L. Suffield, Head of Defence Sales to Private Secretary, Secretary of State for Defence. FCO 8/1914.

41. TNA. 4 August 1971. Annex C of letter from W. Morris, British Embassy, Jedda to A.D. Parsons, FCO. FCO 8/1753.

42. TNA. 3 March 1972. Minute from H.J.L. Suffield, Head of Defence Sales to Private Secretary, Secretary of State for Defence. FCO 8/1914.

43. TNA. 11 January 1972. Minute from H.R. Hubert, DSO, to H.J.L. Suffield, Head of Defence Sales. FCO 8/1914.

44. TNA. 5 August 1971. Note for the file by R. Anderson, MoD. DEFE 13/797. TNA. 18 February 1972. DSO Telegram to British Embassy, Jedda copied to FCO. FCO 8/1914. Fustuq was hired via his firm METICO, a Beirut firm he appears to have run with a Jean Moghabgab. TNA. 9 February 1972. Letter from W. Morris, British Embassy, Jedda to A.D. Parsons, FCO. FCO 8/1914.

45. TNA. 11 January 1972. Minute from H.R. Hubert, DSO, to H.J.L. Suffield, Head of Defence Sales. FCO 8/1914.

46. TNA. 15 January 1965. Submission "Parliamentary Question.” BS 1192/25, FO 371/179888. TNA, 17 January 1966. Letter from A. Miller, MoD, to D. Marston, FO. BS 1192/16, FO 371/185493. TNA. 26 May 1965. Letter from M.S. Weir, FO, to J.M. Brown, British Embassy, Jedda. BS 1192/78, FO 371/179889. TNA. 14 January 1965. Submission “Arms for Saudi National Guard.” BS 1192/25, FO 371/179888.

47. Vickers Archive. 21 October 1968. Minute from J.H. Robbie, Vickers. File 871. This material is produced by permission from the Vickers Archive held at the Cambridge University Library.

48. Vickers Archive. 29 September 1969. Visit to Saudi Arabia - 22 to 26 September 1969, Report by Col. B.S. Heath, Vickers. File 871. This material is produced by permission from the Vickers Archive held at the Cambridge University Library.
49. TNA. 8 July 1971. Letter from H.J.L. Suffield, MoD, to W. Morris, British Embassy, Jedda. FCO 8/1753.

50. TNA. 2 May 1971. Letter from W. Morris, British Embassy, Jedda, to H.J.L. Suffield, MoD. FCO 8/1753.

51. TNA. 20 January 1972. Minute from H.R. Hubert, MoD, to AUS(Sales), MoD. FCO 8/1914.

52. TNA. 8 February 1972. Note of a Meeting with Mr. Khashoggi. FCO 8/1912.

53. TNA. 27 March 1972. Saudi Arabia - Note of a Meeting with Mr. Khashoggi. FCO 8/1914.

54. TNA. 8 May 1972. Minute from H.R. Hubert, MoD, to AUS(Sales), MoD. FCO 8/1920. TNA. 1 November 1972. MoD Telegram No. 011615 to British Embassy, Jedda copied to Cairo. FCO 8/1917.

55. TNA. 22 April 1974. Note for the File "Rapier for Saudi Arabia." FCO 8/2344

56. Guidelines had existed since 1967 under which agents were to be employed by the $\mathrm{MoD}$ "to promote exports where it is clear that the market could not be exploited without their help," the agents had to be "persons or firms of repute" and "remunerated on a basis which reflects the services rendered and can be defended as fair and reasonable." These guidelines, although reasonable sounding, were interpreted by MoD officials, as we have seen, as permitting the use of agents and bribery. TNA. 4 May 1967. Letter from C. Hewertson, MoD to J.A. Patterson, HM Treasury. T 225/2918.

57. TNA. 22 May 1977. Note of a Meeting after lunch at Chequers on Sunday. FV $22 / 117$.

58. TNA. 4 May 1976. Minute from J.F. Howe, MoD, to DUS(FB), MoD. DEFE $68 / 110$.

59. TNA. 9 June 1976. Minute from F. Cooper, MoD to HDS. DEFE 68/110.

60. TNA. 12 January 1977. Letter from Sir Douglas Henley, Exchequer and Audit Department to Sir Frank Cooper, MoD. DEFE 68/110.

61. TNA. 24 March 1977. Minute from Mrs. M. Swaffield, MoD, to DUS(FB), MoD DEFE 23/149. 
(C) www.epsjournal.org.uk - Vol. 3, No. 1 (2008)

62. TNA. 12 January 1977. Letter from Sir Douglas Henley, Exchequer and Audit Department to Sir Frank Cooper, MoD. DEFE 68/110.

63. TNA. 21 February 1977. Letter from A.D. Osborne, Treasury Solicitor's Department, to J.E.D. Street, MoD. DEFE 23/149.

64. TNA. 19 April 1977. Minute from A.D. Osborne, Treasury Solicitor's Department to AUS(Sales), MoD. DEFE 23/149.

65. John Howe held a wide variety of positions on both the management and policy sides of the MoD, including a spell in Northern Ireland in the early 1970s; secondment to the FCO as Counselor in the U.K. Delegation to NATO in the early 1980s; founding Head of the Defense Arms Control Unit; a spell as Private Secretary to the Defense Secretary George Younger (in the mid to late-1980s); and Personnel Director. His last post was as Deputy Chief Executive of the Defense Procurement Agency. Since 2000 he has been the Vice Chairman of Thales U.K.

66. TNA. 2 March 1977. Minute from J.E.D. Street, MoD, to PS/PUS, MoD. DEFE $23 / 149$.

67. TNA. 3 March 1977. Minute from J.F. Howe, MoD, to AUS(Sales Admin), MoD. DEFE 23/149.

68. TNA. 13 April 1977. Minute from J.E.D. Street, MoD, to PS/PUS, MoD. DEFE $23 / 149$.

69. TNA. 2 May 1977. Letter from Sir Frank Cooper, MoD to Sir Douglas Henley, Exchequer and Audit Department. DEFE 68/110.

70. TNA. 27 June 1977. Letter from Sir Frank Cooper, MoD, to Sir Douglas Henley, Exchequer and Audit Department. DEFE 68/110.

71. TNA. 10 August 1977. Letter from Sir Frank Cooper, MoD, to Sir Douglas Henley, Exchequer and Audit Department. DEFE 68/110.

72. TNA. 23 August 1977. Directive from Sir Frank Cooper, MoD to Head of Defence Sales, MoD. DEFE 68/110.

73. TNA. 23 June 1976. Minute from H.J.L. Suffield, MoD, to F. Cooper, MoD. DEFE 23/149. TNA. 23 June 1976. Minute from F. Cooper, MoD, to H.J.L. Suffield. DEFE 23/149.
74. TNA. Undated. Draft minute from H.J.L. Suffield, MoD, to F. Cooper, MoD. DEFE 68/319.

75. An interesting perspective on the dilemma of complicit knowledge came in late 1976 in a discussion between Hugh Braden at DSO and Ivor Lucas, the Head of the Middle East Department at the Foreign and Commonwealth Office (FCO). Braden told Lucas that, as far as agents were concerned, DSO "could not insist on being informed at every point; and sometimes they prefer 'not to know'." Lucas's view was that "what it means is that the arms sales business has its shadowy side by which official circles are best left unsullied." TNA. 29 October 1976. Letter from I.T.M. Lucas, FCO, to D.J. McCarthy, British Embassy, Abu Dhabi. FCO 8/2633.

76. Al Yamamah has reportedly been worth around $£ 43$ billion over the last twenty years.

77. TNA. 6 January 1986. Riyadh Telegram No. ZMC/ZDK/ZBG/A2P to MoD. PJ $5 / 40$.

78. Evans and Leigh (2006) have noted how the price increases in Chandler's telegram are the same as the amount that was "alleged at the time in Arab publications was exacted in secret commissions paid to Saudi royals and their circle of intermediaries in London and Riyadh, as the price of the deal." An investigation by The Times, written after journalists spoke "to sources linked to Al-Yamamah for much of the past 20 years," claimed the price increase was partly due to a weapons upgrade (although the prices quoted in Chandler's telegram excluded spares, equipment, weapons, and training) but conceded that "money almost certainly was paid to middlemen." See Robertson (2007).

79. TNA. 5 March 1974. Minute from P.A. Raftery, FCO, to J.A. Thomson, FCO FCO $8 / 2343$.

80. He had also made him aware that at least one middleman on the sale of BAC Lightning aircraft to Saudi Arabia in the late 1960s had complained he had not received "what he considered as owing to him." The middleman had asked if the U.K government "would consider guaranteeing that BAC would meet their payments to agents." TNA. 8 July 1974. Letter from I.S. McDonald, MoD, to P.R.H. Wright, FCO. FCO 8/2344.

81. See http://www.caat.org.uk/issues/saudi-tna [accessed 22 September 2007].

82. Hirst (2000) 
(C) www.epsjournal.org.uk - Vol. 3, No. 1 (2008)

83. This document was uncovered by David Leigh of The Guardian newspaper following a Freedom of Information request. It is unclear why in November 1994 the directive needed updating. This would have been no routine matter. The 1976 directive was prompted by the Lockheed revelations, and the 1977 directive by the argument between Cooper and Henley over SADAP. It is likely another contentious issue regarding "agents" arose in 1994 prompting the revision. What this issue was is likely to remain a secret for many years hence.

84. Minute from C. France, MoD to HDES, 9 November 1994, available at http://image.guardian.co.uk/sys-files/Guardian/documents/2007/05/29/ch08doc08.pdf [accessed 22 September 2007].

85. Evans and Leigh (2003a).

86. Evans and Leigh (2003b).

87. Evans and Leigh (2003b).

88. Letter from Geoffrey Hoon to Gavin Strang, MP, 26 January 2004, copy on file at CAAT.

89. Evans and Leigh (2007a).

90. Evans and Leigh (2007b)

91. Letter from MoD to David Leigh, The Guardian, 8 August 2006, available at http://image.guardian.co.uk/sys-files/Guardian/documents/2007/05/29/ch08doc08.pdf [accessed 22 September 2007].

92. TNA. 17 January 1977. Minute from Mrs. M. Swaffield, MoD to AUS(Sales Admin), MoD. DEFE 23/149.

93. TNA. 2 June 1977. Letter from Sir Douglas Henley, Exchequer and Audit Department to Sir Frank Cooper, MoD. DEFE 68/110.

94. TNA. 25 January 1978. Letter from D.M.D. Thomas, FCO, to L. Pliatzky, DoT. FV 22/119.

95. Hansard, 26 January 1978.

96. Phythian (2000, pp. 91-92).
97. Evans, et al. (2003).

98. Quadripartite Committee (2004, Ev 34).

99. Quadripartite Committee (2007, paragraph 341, p. 136).

100. Quadripartite Committee (2004, Ev 34).

101. Roeber (2005, p. 5).

102. Robertson (2007).

103. House of Lords, Hansard, 14 December 2006, col. 1712.

104. Hawley (2003, p. 17).

105. TNA. 2 February 1967. Letter from H.R. Hubert, MoD, to D.N. Brinson, British Embassy, Caracas. FCO 46/190.

106. There is a growing amount of literature on the subject - principally researched by the author, Rob Evans, and David Leigh. See for example Gilby (2005), the BBC Newsnight documentary (see http://www.caat.org.uk/issues/saudi-bribery.php) of 16 June 2006 (researched by the author), and the Al Jazeera documentary of February 2007 "Trail of the Dove" (researched by the author). The author has also written a forthcoming book Arms and Bribes: The Untold History of Britain and the House of Saud. The Guardian have published many documents in a major investigation "The BAE files" at www.guardian.co.uk/baefiles. Much of the material was researched by the author.

\section{References}

Adams, C., Burns, J., and Peel, M. 2007. "Goldsmith Reveals Saudi Royal Dilemma." Financial Times. 31 January 2007.

Boulton, D. 1978. The Lockheed Papers. London: Jonathan Cape.

[Quadripartite Committee] Defence, Foreign Affairs, International Development and Trade and Industry Committees. 18 May 2004. "Strategic Export Controls: Annual Report for 2002, Licensing Policy and Parliamentary Scrutiny." HC390.

[Quadripartite Committee] Defence, Foreign Affairs, International Development and Trade and Industry Committees. 3 August 2006. "Strategic Export Controls: Annual Report for 2004, Quarterly Reports for 2005, Licensing Policy and Parliamentary Scrutiny." HC873.

[Quadripartite Committee] Defence, Foreign Affairs, International Development and 
Trade and Industry Committees. 23 July 2007. "Strategic Export Controls: 2007 Review." HC117.

Evans, R. and Leigh, D. 2003a. "BAE Accused of Arms Deal Slush Fund." The Guardian [London]. 11 September 2003. http://politics.guardian.co.uk/print/ 0,,4751055-107982,00.html [accessed 23 September 2007].

Evans, R. and Leigh, D. 2003b. "MoD Chief in Fraud Cover-Up Row." The Guardian [London]. 13 October 2003. http://politics.guardian.co.uk/foi/story/0,,1061673,00. html [accessed 23 September 2007].

Evans, R. and Leigh, D. 2006. "The Secret Whitehall Telegram that Reveals Truth Behind Controversial Saudi Arms Deal." The Guardian [London]. 28 October 2006. http://politics.guardian.co.uk/foi/story/0,,1933764,00.html [accessed 23 September 2007].

Evans, R. and Leigh, D. 2007a. "BAE Accused of Secretly Paying £1bn to Saudi Prince." The Guardian [London]. 7 June 2007. http://www.guardian.co.uk/ baefiles/story/0,,2097149,00.html [accessed 23 September 2007].

Evans, R. and Leigh, D. 2007b. "MoD Accused Over Role in Bandar's £1bn.” The Guardian [London]. 12 June 2007. http://www.guardian.co.uk/baefiles/story/ 0,2100761,00.html [accessed 23 September 2007].

Evans, R., Carroll, R., Harding, L., and Traynor, I. 2003. "Web of State Corruption Dates Back 40 Years." The Guardian [London]. 13 June 2003. http://www.guardian.co.uk/armstrade/ story/0,,976559,00.html [accessed 23 September 2007].

Gilby, N. 2005. "The UK Government and Arms Trade Corruption: A Short History." London: Campaign Against Arms Trade.

Hawley, S. 2003. Turning a Blind Eye: Corruption and the UK Export Credits Guarantee Department. Sturminster Newton: The Corner House.

Hirst, C. 2000. "The Arabian Connection: The UK Arms Trade to Saudi Arabia." London: Campaign Against Arms Trade.

Ministry of Defence. 2005. "Defence Industrial Strategy." (December). Cm 6697.

OECD. 2000. "United Kingdom: Review of the Implementation of the Convention and 1997 Recommendation." Paris: OECD.

OECD. 2003. "United Kingdom: Review of the Implementation of the Convention and 1997 Recommendation, Phase 1 Bis Report." Paris: OECD.

OECD. 2005. "United Kingdom Phase 2: Report on the Application of the Convention on Combating Bribery of Public Officials in International Business Transactions and the 1997 Recommendation on Combating Bribery in International Business Transactions." Paris: OECD.

Phythian, M. 2000. The Politics of British Arms Sales Since 1964. Manchester: Manchester University Press.

Robertson, D. 2007. “Al-Yamamah: An Echo of 1980s Sleaze.” The Times [London]. 21 February 2007.

Roeber, J. 2005. "Parallel Markets: Corruption in the International Arms Trade."
London: Campaign Against Arms Trade.

Sampson, A. 1977. The Arms Bazaar: From Lebanon to Lockheed. London: Viking Press. 